\title{
Studi Sosio-Historis Tradisi Keilmuan dan Karakteristik Pendidikan Islam di Dusun Sekardangan
}

\author{
Arif Muzayin Shofwan \\ Universitas Nahdlatul Ulama Blitar, Indonesia \\ Email: arifshofwan2@gmail.com
}

\begin{tabular}{l}
\hline Tersedia Online di \\
\hline http://www.jurnal.unublitar.ac.id/ \\
index.php/briliant \\
\hline Sejarah Artikel \\
\hline Diterima pada 1 Oktober 2020 \\
Disetuji pada 16 November 2020 \\
Dipublikasikan pada 30 \\
November 2020 \\
Hal. 781-795 \\
\hline Kata Kunci: \\
\hline Sosio-Historis; Institusi; \\
Pendidikan Islam; Karakteristik \\
\hline DOI: \\
\hline http://dx.doi.org/10.28926/briliant \\
.v3i4.563
\end{tabular}

\begin{abstract}
Abstrak: Proses terbentuknya institusi pendidikan Islam formal pertama di Dusun Sekardangan, merupakan sejarah panjang yang dimulai dari rumah kiai, langgar (mushalla), masjid, pesantren, dan madrasah diniyah. Tulisan ini bertujuan menggali sosio-historis berdirinya institusi pendidikan Islam formal pertama di dusun tersebut beserta karakteristiknya. Penelitian kualitatif dengan pendekatan diskriptif-analitis ini menyebutkan bahwa MI Miftahul Huda 01 dan TK Al-Hidayah 01 merupakan institusi pendidikan Islam formal yang dahulu berawal dari pendidikan Islam di rumahrumah kiai persis sebagaimana pendidikan Islam awal jaman Nabi Muhammad SAW yang berada di rumah sahabat Al-Arqam (Dar al-Arqam). Pertama, karakteristik pengajaran Islam masa awal berdirinya dusun menggunakan tembang-tembang macapat dan syair-syair lainnya. Kedua, karakteristik pengajaran sebelum formal menggunakan sistem pengajaran tradisional berupa sorogan, bandongan, musyawarah, dan ceramah/tablig. Ketiga,
\end{abstract} karakteristik ketika telah menjadi formal dilakukan melalui sistem pembelajaran modern dengan beragam metode pengajaran, di antaranya: metode ceramah, diskusi, eksperimen, demonstrasi, pemberian tugas, sosiodrama, drill, kerja kelompok, tanya jawab, proyek, dan lainnya.

\section{PENDAHULUAN}

Sejak jaman Rasulullah SAW kelembagaan pendidikan Islam itu memang sudah ada, baik yang bersifat fisik maupun yang bersifat non fisik. Langgulung (2003: 17-18) dan Shalabi (1954: 41) mejelaskan bahwa pada zaman permulaan Islam, pelajaran agama Islam disampaikan di rumah-rumah. Rasulullah SAW menjadikan rumah sahabat Arqam bin Abi al-Arqam sebagai tempat belajar dan tempat pertemuan dengan para sahabat dan para pengikutnya. Di rumah tersebut Rasulullah SAW menyampaikan dasar-dasar agama dan pengajian Al-Qur'an. Selain rumah al-Arqam (Dar al-Arqam), Rasulullah SAW menyampaikan pelajaran agama Islam dirumahnya sendiri di Mekkah sebagai tempat kaum muslimin berkumpul mempelajari akidah dan syariah Islam. Nizar (2005: 6) menyebutkan bahwa pendididan Islam yang berlangsung di rumah tersebut berlangsung kurang lebih selama tiga belas tahun. Adapun sistem dan materi pendidikan yang disampaikan diserahkan sepenuhnya kepada Nabi Muhammad SAW.

Penghijrahan Rasulullah SAW ke Madinah pada tahun 623 masehi membawa perubahan dan pengertian yang besar terhadap penyebaran dan 
kestabilan agama Islam. Bagi tujuan tersebut, masjid didirikan pula di Madinah, seperti Masjid Quba dan Masjid Nabawi. Fungsi masjid dalam tradisi Islam adalah sebagai markas bagi segala aktifitas agama dan masyarakat, khususnya dalam halhal yang berhubungan dengan ibadah dan pendidikan. Rasulullah SAW menjadikan Masjid Nabawi sebagai tempat belajar mengenai urusan dunia dan agama di samping beribadah kepada Allah SWT. Situasi di masjid menjadikannya lebih bebas dan sesuai sebagai tempat belajar dari pada di rumah, karena di masjid seseorang tidak perlu meminta kebenaran untuk memasukinya jika dibandingkan pendidikan dengan di rumah-rumah (Langgulung, 2003: 18; Al-Abrashi, 1969: 65).

Sementara itu, Soebahar (2002: 92) menyatakan bahwa tatkala Rasulullah SAW hijrah ke Madinah, kegiatan pendidikan Islam tidak lagi berlangsung secara diam-diam atau perorangan di rumah-rumah, melainkan telah mengambil tempat strategis di serambi masjid dan di dalam masjid sekaligus. Bilgrami dan Ashraf (1985: 18-20) menggambarkan bahwa selain masjid, tempat pendidikan Islam berupa As-Suffah juga didirikan sebagai tempat pemukiman di salah satu ruangan yang berdekatan dan bergandengan dengan masjid. As-Suffah menjadi tempat yang dipakai oleh Rasulullah SAW untuk mendidik (Arifin, 2002: 23). Hal tersebut merupakan suatu pola pendidikan Islam yang pernah dicetuskan oleh Rasulullah SAW dan dikuti selama berabad-abad oleh umat Islam. Di tempat itulah Rasulullah SAW mengajar menghafal Al-Qur'an secara benar dan mengangkat Ubaid ibn AlSamit sebagai pendidik pada lembaga pendidikan As-Suffah di Madinah.

Berawal dari lembaga pendidikan berupa rumah kiai, masjid, serambi masjid, langgar (mushalla), As-Suffah, dan semacamnya, kemudian di Indonesia muncul lembaga pendidikan Islam yang disebut pesantren. Istilah "pesantren" secara etimologis berasal dari kata pe-santri-an, berari "tempat para santri" (Ziemek, 1986: 16). Dhofier (1994: 44) mendefinisikan bahwa pesantren adalah sebuah asrama pendidikan Islam tradisional, di mana para siswanya tinggal bersama dibawah bimbingan seorang (atau lebih) guru, yang lebih dikenal dengan sebutan kiai. Sedangkan Qomar (2007: 2) menjelaskan bahwa definisi pondok pesantren adalah suatu lembaga pendidikan agama Islam yang tumbuh serta diakui masyarakat sekitar dengan sistem asrama, di mana santri-santri menerima pendidikan agama melalui sistem pengajian atau madrasah yang sepenuhnya berada di bawah kedaulatan dari leadership seorang atau beberapa kiai dengan ciri-ciri khas yang bersifat kharismatik serta independen dalam segala hal. Daulay (2009: 21) menyebutkan bahwa pesantren pertama muncul di Indonesia didirikan oleh Maulana Malik Ibrahim Gresik, yang selanjutnya disusul berdirinya pesantrenpesantren lain hingga kini.

Sementara itu, istilah lembaga diartikan sebagai badan atau yayasan yang bergerak dalam bidang penyelenggaraan pendidikan atau kemasyarakatan (Partanto dan Al-Barry, 1994: 406). Sedangkan arti kelembagaan pendidikan Islam sebagaimana pendapat Ramayulis (2002: 216) dapat dijelaskan bahwa arti lembaga dalam pengertian fisik disebut institute merupakan sarana atau organisasi untuk mencapai tujuan tertentu, sedangkan pengertian lembaga dalam arti non-fisik atau abstrak disebut institution merupakan suatu sistem norma untuk memenuhi kebutuhan. Selain itu, lembaga dalam arti fisik disebut bangunan dan lembaga arti non-fisik disebut pranata.

Berdasarkan pendapat Ramayulis di atas dapat dipahami bahwa pengertian lembaga pendidikan Islam tidak bisa dipandang hanya dari segi fisik seperti

782 BRILIANT: Jurnal Riset dan Konseptual Volume 5 Nomor 4, November 2020 
bangunan saja. Akan tetapi lebih dari itu, lembaga pendidikan Islam harus pula dipandang dari segi non-fisik seperti sistem norma-norma maupun nilai-nilai (values) yang dikembangkan. Yakni, sebuah sistem norma-norma maupun nilainilai (values) yang telah melembaga dalam tradisi Islam itu sendiri juga dinamakan lembaga pendidikan dalam arti non-fisik.

Berawal dari uraian di atas, tampak bahwa perspektif sosio-historis terbentuknya kelembagaan pendidikan Islam formal di Dusun Sekardangan, Kecamatan Kanigoro, Kabupaten Blitar yang telah mengalami perubahan dari waktu ke waktu sangat menarik untuk diteliti. Tampak bahwa lembaga pendidikan Islam formal di dusun tersebut ternyata pada awalnya berangkat dari beberapa institusi non-formal sebelumnya, seperti: rumah kiai, langgar (mushalla), pesantren, masjid, madrasah diniyah hingga menjadi institusi pendidikan Islam formal pertama berupa MI Miftahul Huda 01 dan TK Al-Hidayah 01. Yakni, sebuah lembaga pendidikan Islam di Dusun Sekardangan yang dipandang lebih maju daripada lembaga-lembaga pendidikan Islam non-formal sebelumnya.

Oleh karena itu, tulisan ini akan membahas tiga hal, yaitu: (1) Sekilas tentang Dusun Sekardangan dan karakteristik pendidikan Islam masa awal; (2) Perspektif sosio-historis tentang institusi/lembaga pendidikan Islam di Dusun Sekardangan dari masa ke masa hingga terbentuknya institusi/lembaga pendidikan Islam formal pertama berupa MI Miftahul Huda Papungan 01 dan TK. Al-Hidayah 01; (3) Karakteristik sistem pembelajaran pendidikan Islam di Dusun Sekardangan, baik ketika masa awal berdirinya dusun, masa masih non-formal maupun tatkala telah menjadi lembaga yang formal seperti saat ini.

\section{METODE}

Tulisan tentang studi pendidikan Islam dari masa ke masa di Dusun Sekardangan Kecamatan Kanigoro Kabupaten Blitar ini merupakan penelitian kualitatif dengan menggunakan pendekatan diskriptif-analitis dalam proses penelitiannya. Penelitian ini juga dikatakan studi kasus (case study) dengan alasan karena studi ini dilakukan terhadap suatu sistem, yang berupa program, kegiatan, peristiwa, atau sekelompok individu yang terikat oleh tempat, waktu dan ikatan tertentu (Stake, 1994), yakni proses terbentuknya pendidikan Islam formal pertama beserta karakteristiknya di Dusun Sekardangan.

Selain itu, penelitian ini juga disebut penelitian kualitatif dikarenakan memiliki lima karakteristik yang menurut Bogdan dan Biklen, yaitu: (1) naturalistik; (2) deskriptif; (3) perhatian pada proses; (4) induktif; dan (5) perhatian pada makna. Tentu saja, karena penelitian ini juga berlatar sejarah, digunakan pula studi kepustakaan (library research) yang menurut Nazir (2011: 27) diartikan sebagai sebuah pengumpulan data yang dilakukan dengan penelaahan terhadap buku-buku, literatur-literatur, catatan-catatan, dan laporan-laporan yang ada hubungannya dengan masalah yang dipecahkan.

Muhadjir (1996: 169) menyatakan bahwa studi kepustakaan (library research) lebih memerlukan olahan filosofis dan teoritis daripada uji empiris di lapangan. Dengan demikian, oleh karena sifatnya yang filosofis dan teoritis, maka penelitian kepustakaan sering menggunakan pendekatan filosofis (philosophical approach) daripada pendekatan yang lainnya. Begitu pula, oleh karena hal yang demikian itu pula, metode penelitiannya mencakup sumber data, pengumpulan data, dan analisis data. 
Teknik pengumpulan data menggunakan observasi, wawancara mendalam (in dept interview), dan dokumentasi. Observasi digunakan untuk melakukan pengamatan terhadap kondisi sosial yang ada di Dusun Sekardangan demi menentukan informan utama. Penentuan informan selanjutnya dilakukan dengan prinsip bola salju (snow-ball). Observasi dilakukan dengan terus terang kepada sumber data (Sugiyono, 2010). Wawancara mendalam digunakan untuk menggali sosio-historis tradisi keilmuan dan karakteristik pendidikan di Dusun Sekardangan dari masa ke masa. Sedangkan dokumentasi digunakan untuk melengkapi kegiatan observasi dan wawancara mendalam.

Teknik analisis data menggunakan deskriptif-eksploratif yang melibatkan empat komponen model Spradley (1980) yaitu: analisis domain (domain analysis), taksonomi (taxonomic analysis), komponensial (componential analysis), dan tema kultural (discovering cultural theme). Dengan demikian, pertama kali peneliti memasuki obyek penelitian yaitu Dusun Sekardangan dengan memperhatikan situasi sosial (place, actor, activity) yang ada, kemudian menetapkan informan kunci (key informant) dan melakukan wawancara. Setelah itu, peneliti lalu melakukan serangkaian empat komponen tersebut.

\section{HASIL}

Studi ini menghasilkan beberapa temuan. Pertama, pendidikan Islam formal pertama di Dusun Sekardangan Kecamatan Kanigoro Kabupaten Blitar bisa terbentuk sedemikian rupa di awali dari beragam pendidikan Islam masa awal yang diselenggarakan di rumah-rumah para kiai sebagaimana pendidikan Islam awal jaman Nabi Muhammad SAW di rumah sahabat Al-Arqam (Dar al-Arqam), langgar (mushalla), masjid, pesantren dan madrasah diniyah. Kedua, pendidikan Islam formal pertama di Dusun Sekardangan Desa Papungan Kecamatan Kanigoro Kabupaten Blitar adalah berupa MI Miftahul Huda 01 dan TK Al-Hidayah 01 berdiri dan diresmikan pada tanggal 5 Januari 1966.

Bermula dari dua temuan di atas kemudian menghasilkan tiga analisis terpenting, yaitu: (1) pendidikan Islam di Dusun Sekardangan seputar abad 15-16 M, semasa cikal-bakal mendirikan atau bedol dusun tersebut memiliki karakteristik sistem pengajaran yang masih sangat sederhana, yakni melalui tembang-tembang macapat dan syair-syair lainnya; (2) pendidikan Islam di Dusun Sekardangan sebelum tahun 1966 memiliki karakteristik dan sistem pengajaran tradisional dengan menggunakan metode sorogan, bandongan, musyawarah, dan ceramah/tablig; dan (2) pendidikan Islam di Dusun Sekardangan dimulai adanya MI Miftahul Huda 01 dan TK Al-Hidayah 01 berdiri dan diresmikan pada tanggal 5 Januari 1966 memiliki karakteristik dan sistem pengajaran modern dengan berbagai metode pengajaran, di antaranya: metode ceramah, diskusi, eksperimen, demonstrasi, pemberian tugas, sosiodrama, drill, kerja kelompok, tanya jawab, proyek, dan lainnya.

Terakhir, walau para kiai dan tokoh pendidikan di Dusun Sekardangan Desa Papungan Kecamatan Kanigoro Kabupaten Blitar seiring berjalannya waktu telah memasukkan dan membuka diri terhadap pendidikan Islam modern, mereka tidak lantas meninggalkan pendidikan Islam tradisional. Hal itu terbukti ketika metode pembelajaran Islam tradisional (seperti sorogan, bandongan, musyawarah, dan ceramah/tablig) ternyata juga tetap digunakan pada lembaga pendidikan Islam hingga sekarang, seperti: di mushalla, masjid, madrasah diniyah, dan semacamnya.

784 BRILIANT: Jurnal Riset dan Konseptual Volume 5 Nomor 4, November 2020 
Demikian ini karena tokoh pendidikan di dusun tersebut rata-rata kaum Nahdliyin yang memiliki keteguhan dalam memegang erat idiom "al-muhafadhah alal qadimis shalih wal akhdu bil jadidil ashlah" (menjaga tradisi lama yang baik dan mengambil tradisi baru yang lebih baik) tetap terjaga hingga kini.

\section{PEMBAHASAN}

\section{Sekilas Dusun Sekardangan \& Pendidikan Islam Awal}

Penelitian ini dilakukan di sebuah Dusun Sekardangan, yakni sebuah dusun yang sejuk dan asri serta berada di pinggiran kota dan kabupaten Blitar. Perlu diketahui bahwa Sekardangan merupakan sebuah dusun kecil yang berada di Desa Papungan, Kecamatan Kanigoro, Kabupaten Blitar, Propinsi Jawa Timur. Menurut Kiai Zainuddin (4/5/2020) dinyatakan bahwa dusun tersebut didirikan oleh tiga orang tokoh, yaitu Ki Kebo Kanigoro (Kiai Purwoto Sidik), istrinya Nyai Sekardinah (Nyi Gadhung Melati), dan putrinya Rara Tenggok (Rara Sekar Rinonce) pada zaman perpolitikan Kerajaan Islam Demak, Pajang hingga Mataram. Hasil daari wawancara Bapak Gunawan (14/1/2020) dan Bapak Mayar (15/1/2020) diperoleh informasi bahwa ketiga tokoh tersebut juga diakui sebagai tokoh pendiri Kelurahan Kanigoro (di Kecamatan Kanigoro), yakni sebuah kecamatan yang berada di Kabupaten Blitar. Istilah "Kanigoro" sebagai sebuah kecamatan di Blitar bagian tengah diambil dari seorang tokoh yang bernama Ki Kebo Kanigoro (Kiai Purwoto Sidik) pada zaman pergolakan politik kerajaan Islam Demak Bintara dan Pajang.

Dikisahkan oleh Bapak Mansuri (11/1/2020) bahwa pada masa pergolakan politik Kerajaan Demak Bintara dan awal berdirinya kerajaan Islam Pajang, Ki Kebo Kanigoro (Kiai Purwoto Sidik) dan istrinya Nyai Sekardinah (Nyai Gadhung Melati) bersama putrinya yang bernama Rara Tenggok (Rara Sekar Rinonce) hijrah sampai di sebuah daerah di Kabupaten Blitar yang nantinya disebut dengan Kelurahan/Kecamatan Kanigoro. Hal tersebut konon karena Ki Kebo Kanigoro (Kiai Purwoto Sidik) merupakan otak intelektual pendirian kerajaan Islam Pajang yang menjadi paman dan guru spiritual dari Jaka Tingkir (Sultan Hadiwijaya). Dalam pergolakan politik tersebut, Jaka Tingkir sendiri dikisahkan juga pernah singgah di Kanigoro hingga akhirnya hijrah munuju ke Lamongan sampai wafat dan dimakamkan di sana. Selain itu, dikisahkan bahwa Ki Kebo Kanigoro (Kiai Purwata Sidik) juga merupakan murid dari Syaikh Siti Jenar (Syaikh Abdul Jalil) sehingga beliau selalu menjadi buronan rezim perpolitikan Kerajaan Islam Demak Bintara.

Sesampai ketiga tokoh (Ki Kebo Kanigoro, Nyai Sekardinah, dan Rara Tenggok) tersebut di sebuah tempat, ketiganya kemudian mendirikan sebuah rumah yang hingga saat ini dikenal sebagai "Petilasan Jatikurung" yang berada di Kelurahan Kanigoro, tepatnya berada di tengah-tengah Kecamatan Kanigoro, Kabupaten Blitar (Shofwan, 2016: 6). Ketika ketiga tokoh tersebut bermukim di tempat tersebut, hingga saat itu ketiganya banyak meresmikan berdirinya sebuah dusun maupun desa yang berada di wilayah Kecamatan Kanigoro-Blitar. Maka tak heran, apabila kebanyakan tempat dan daerah di wilayah Kecamatan Kanigoro terdapat banyak petilasan ketiga tokoh tersebut yang hingga saat ini diabadikan sebagai monumen atau istilah Jawa-nya dinamakan sadranan, seperti di Dusun Sekardangan (Desa Papungan); Dusun Buntu (Desa Tlogo); Dusun Dogong, Sawentar, Bendelonje, dan lainnya. Sadranan adalah sebuah petilasan para tokoh 
yang akhirnya sepeninggal tokoh tersebut telah tiada, lalu dibuatkan monumen sebagai tempat untuk mengenang serta mengirimkan doa yang ditujukan pada para tokoh tersebut.

Dikisahkan oleh Bapak Mansuri (11/1/2020) bahwa ketika pergolakan politik ketiga kerajaan (yakni; Demak, Pajang, dan awal berdirinya Mataram) agak mereda, kemudian Ki Kebo Kanigoro (Kiai Purwoto Sidik) tanpa didampingi istri dan anaknya terlebih dahulu kembali ke Sukoharjo, Solo. Namun sebelum kepulangan Ki Kebo Kanigoro ke Sukoharjo-Solo, beliau menempatkan istrinya Nyai Sekardinah (Nyai Gadhung Melati) dan Rara Tenggok (Rara Sekar Rinonce) di sebuah tempat yang nantinya disebut Dusun Sekardangan, berjarak tiga kilometer dari "Petilasan Jatikurung" Kanigoro-Blitar. Bapak Jawoko (5/2/2020) menyatakan bahwa petilasan ketiga tokoh tersebut biasanya ditandai dengan tanaman Pohon Jati sebagai sandi. Bisa disebutkan beberapa petilasan ketiganya yang ditanami Pohon Jati, di antaranya: Petilasan Jatibendo berada di Dusun Dogong, Kanigoro, Blitar; Petilasan Jatikucur berada di Desa Selokajang, Srengat, Blitar; Petilasan Jatigerot berada di Desa Maliran, Ponggok, Blitar; Petilasan Jatinom berada di Desa JatinomBlitar; Petilasan Jatibedug berada di Dukuh Kaligayam Lor, Rejosari, Samin; dan lain sebagainya.

Dikisahkan oleh Kiai Zainuddin (6/4/2020) bahwa setelah cukup lama Nyai Sekardinah (Nyai Gadhung Melati) dan Rara Tenggok (Rara Sekar Rinonce) berada di tempat yang disebutkan di atas, kemudian keduanya berniat kembali menyusul Ki Kebo Kanigoro (Kiai Purwoto Sidik) yang telah lama kembali ke SukoharjoSolo. Namun, sebelum Nyai Sekardinah dan Rara Tenggok kembali ke Sukoharjo, beliau (Nyai Sekardinah) tanpa didampingi Rara Tenggok menjenguk anaknya yang bernama Ki Ageng Gribig I (Pangeran Kedhanyang) di Malang-Jatim. Setelah beberapa hari Nyai Sekardinah berada di rumah Ki Ageng Gribig I, beliau lalu mendengar kabar bahwa Rara Tenggok yang ditinggalkannya di Dusun Sekardangan mengalami sakit keras. Mendengar kabar tersebut, Nyai Sekardinah lalu kembali pulang ke Dusun Sekardangan. Sesampai Nyai Sekardinah di Sekardangan, ternyata Rara Tenggok telah sembuh dari sakit kerasnya. Oleh karena kejadian tersebut, maka daerah tersebut dinamakan Dusun Sekardangan. Artinya, ketika Nyai Sekardinah sampai di daerah tersebut, ternyata Rara Tenggok (Rara Sekar Rinonce) telah sembuh (dangan: Jw) dari sakit kerasnya. Menurut Bapak Mayar (15/1/2020) bahwa kesembuhan Rara Tenggok tersebut karena diterapi dengan aroma Bunga Melati yang konon banyak memiliki khasiat. Dengan demikian, tak heran bila Dusun Sekardangan pada masa lalu banyak ditumbuhi tanaman Bunga Melati.

Setelah pergolakan politik antara Kerajaan Islam Demak Bintara, Pajang dan awal berdirinya Mataram semakin membaik, kemudian Nyai Sekardinah dan Rara Tenggok benar-benar memutuskan kembali menyusul Ki Kebo Kanigoro suaminya ke Sukoharjo-Solo. Sementara itu, ada beberapa punggawa ketiga tokoh tersebut yang tetap berada di Dusun Sekardangan dan tidak ingin kembali ke Sukoharjo-Solo Raya. Para punggawa yang ditinggal ketiga tokoh (Ki Kebo Kanigoro, Nyai Gadhung Melati, dan Rara Tenggok) pulang ke Sukoharjo-Solo Raya itulah yang kemudian menurunkan beberapa keturunan di Dusun Sekardangan hingga menurunkan anak cucu dan cicit hingga sekarang. Selanjutnya, Shofwan (2016: 17-18) menyebutkan bahwa setelah ketiga tokoh (Ki Kebo Kanigoro, Nyai Gadhung Melati, dan Rara Tenggok) wafat, maka jasad ketiganya dimakamkan di

786 BRILIANT: Jurnal Riset dan Konseptual Volume 5 Nomor 4, November 2020 
Dusun Sarehan, Desa Jatingarang, Kecamatan Weru, Kabupaten Sukoharjo (Solo Raya). Sementara, petilasan ketiga tokoh sebagai cikal bakal Dusun Sekardangan tersebut masih terawat baik oleh warga masyarakat setempat yang biasa digunakan acara nyadran, mengenang jasa-jasa, tahlil kirim doa arwah cikal-bakal (ketiga tokoh tersebut), dan Ritual Bersih Dusun setiap malam Selasa Kliwon pada Bulan Muharram.

Tak dapat ditelusuri jejaknya mengenai bagaimana institusi pendidikan Islam pada masa ketiga tokoh tersebut ketika awal menjadi cikal-bakal dan bedol Dusun Sekardangan. Namun dikisahkan oleh Bapak Nuruddin (19/3/2020) bahwa petilasan ketiga tokoh yang berada di Dusun Sekardangan dan lazim disebut oleh warga sekitar sebagai "Petilasan Eyang Sekardangan" itu dahulu kala merupakan sebuah langgar (mushalla) kecil yang biasa dipakai untuk beribadah dan mengajarkan keagamaan Islam. Ada kemungkinan bahwa karakteristik pengajaran pendidikan Islam kala itu diajarkan secara sederhana, di antaranya melalui tembang-tembang macapat. Sebab pengajaran melalui tembang-tembang macapat inilah yang biasa digunakan para tokoh Islam pada zaman Kerajaan Demak Bintara, Pajang, dan Mataram. Misalnya, pada masa-masa itu Sunan Kalijaga banyak mengajarkan nilai-nilai Islam melalui Kidung Rumeksa Ing Wengi dalam bentuk macapat. Begitu pula wali-wali pada masa Walisanga dan setelahnya (yakni; Masa Pajang dan Mataram), juga menggunakan media tembang macapat untuk mendidik masyarakat Jawa. Dengan demikian, ada banyak kemungkinan bahwa pengajaran pendidikan Islam di langgar (mushalla) yang didirikan ketiga tokoh cikal-bakal Dusun Sekardangan tersebut disampaikan melalui berbagai macam tembang macapat atau syair-syair lainnya.

\section{Sosio-Historis Terbentuknya Pendidikan Islam Formal Pertama}

Secara garis besar, perspektif sosio-historis terbentuknya institusi pendidikan Islam formal pertama di Dusun Sekardangan, Desa Papungan, Kecamatan Kanigoro, Kabupaten Blitar di awali dari lembaga/institusi pendidikan Islam yang sangat sederhana berupa rumah kiai, langgar (mushalla), masjid, pesantren, dan madrasah diniyah. Oleh karena proses terbentuknya inststitusi pendidikan Islam formal pertama di dusun tersebut tidak bisa lepas dari lembagalembaga sebelumnya, maka lembaga pendidikan Islam dalam studi ini terbagi menjadi tiga bagian, sebagaimana berikut.

Pertama, zaman institusi pendidikan Islam pasca berdirinya Dusun Sekardangan sekitar abad ke-154-16 M menggunakan langgar (mushalla) yang didirikan cikal-bakal dalam mengajarkan pendidikan Islam. Kedua, zaman institusi pendidikan Islam non-formal tahun 1700-1966, yakni pada masa masyarakat Dusun Sekardangan masih menggunakan lembaga pendidikan Islam berupa rumah kiai, langgar (mushalla), masjid, pesantren, dan madrasah diniyah. Ketiga, zaman institusi pendidikan Islam formal mulai tahun 1966 hingga sekarang, yakni pada masa Dusun Sekardangan mulai memiliki lembaga pendidikan Islam formal pertama berupa MI Miftahul Huda 01 dan TK Al-Hidayah 01 hingga sekarang.

Walaupun sudah memiliki lembaga pendidikan Islam formal, namun hingga kini sebagian masyarakat Dusun Sekardangan masih pula menggunakan lembagalembaga non-formal sebagai sarana belajar-mengajar keilmuan Islam sebagaimana yang telah disebutkan. Selanjutnya, oleh karena tidak adanya catatan data tertulis pendukung tentang institusi pendidikan Islam di era berdirinya Dusun Sekardangan 
(abad ke-15-16 M), maka dalam penelitian ini akan langsung dibahas mengenai penjelasan perspektif sosio-historis dari kedua lembaga pendidikan pasca antara abad tersebut, sebagai berikut:

1. Zaman Institusi Pendidikan Islam Non-Formal (1700-1966)

Ketika masyarakat Dusun Sekardangan belum memiliki pendidikan Islam formal, maka institusi pendidikan untuk mengajarkan keislaman yang digunakan adalah rumah kiai, langgar (mushalla), masjid, pesantren, dan madrasah diniyah. Rumah-rumah kiai di Dusun Sekardangan merupakan institusi/lembaga pendidikan Islam pertama sebelum terbentuknya sebuah tempat ibadah berupa langgar (mushalla). Selanjutnya, institusi pendidikan Islam di Dusun Sekardangan berupa masjid merupakan tempat pengajaran keilmuan Islam yang lebih besar dibandingkan langgar (mushalla). Dalam studi ini, setelah berdirinya institusi pendidikan Islam berupa masjid, kemudian berdiri sebuah pesantren di sampingnya. Adapun lembaga pendidikan Islam yang disebutkan terakhir (yakni madrasah diniyah) merupakan lembaga yang cara pengelolaannya lebih tertata dibanding empat (4) lembaga pendidikan Islam yang tersebut di awal (yakni: rumah-rumah kiai, mushalla, masjid, dan pesantren). Sementara itu, sebuah pesantren pertama di Dusun Sekardangan memiliki cara pengelolaan yang lebih sederhana dibanding madrasah diniyah walau sudah memiliki kemajuan dibanding lembaga/institusi pendidikan Islam sebelumnya.

Tidak bisa diketahui secara pasti kapan tanggal, bulan, dan tahun berdirinya institusi pendidikan Islam pertama berupa langgar (mushalla) di Dusun Sekardangan. Sebab memang tidak ada sedikitpun data-data tertulis yang dapat dipakai untuk memperkuat sejarah berdirinya institusi pendidikan Islam berupa langgar (mushalla) pertama di dusun tersebut. Namun, bisa diperkirakan bahwa terbentuknya institusi pendidikan Islam berupa langgar (mushalla) pertama di dusun tersebut berkisar abad ke-17-an masehi. Hal tersebut didasarkan patokan pada generasi berapa keturunan pendiri institusi pendidikan Islam berupa langgar (mushalla) tersebut pada saat studi ini dilakukan. Yakni, pada saat studi ini dilakukan, rata-rata generasi keturunan para pendiri institusi pendidikan Islam berupa langgar (mushalla) pertama di Dusun Sekardangan tersebut menempati generasi ke-7 sampai ke-9. Adapun para keturunan yang menempati generasi tersebut di antaranya adalah keturunan dari pendiri institusi pendidikan Islam berupa langgar yang didirikan oleh Kiai Atmo Setro, Kiai Abu Yamin, Kiai Barnawi, dan Kiai Kasan Muhtar. Yakni, keempat tokoh inilah yang sekitar abad 17 masehi mendirikan institusi pendidikan Islam berupa langgar (mushalla) pertama di samping atau depan rumah masing-masing yang biasa dipakai masyarakat Dusun Sekardangan kala itu untuk belajar ilmu agama Islam.

Selanjutnya, pada abad ke-18 masehi berdiri pula institusi pendidikan Islam berupa langgar (mushalla) dari para keturunan para kiai yang telah disebutkan di atas. Bisa disebutkan langgar (mushalla) yang berdiri sekitar abad ke-18 hingga awal abad ke-19 di antaranya langgar Kiai Abdurrahman; langgar yang didirikan oleh Kiai Imam Ghozali; dan langgar yang didirikan oleh Kiai Zainuddin. Adapun fungsi semua langgar (mushalla) kala itu digambarkan oleh Daulay (2009: 20-21) untuk tempat pendidikan orang dewasa maupun anak-anak. Pengajian bagi orangorang dewasa adalah penyampaian-penyampaian ajaran Islam kepada para jamaah dalam bidang akidah, ibadah dan akhlak. Sedangkan pengajian yang dilaksanakan bagi anak-anak berpusat kepada pengajian Al-Qur'an menitik beratkan kepada

788 BRILIANT: Jurnal Riset dan Konseptual

Volume 5 Nomor 4, November 2020 
kemampuan membaca dengan baik sesuai dengan kaidah-kaidah bacaan, selain dari itu anak-anak juga diberikan pendidikan keimanan, ibadah dan akhlak.

Hingga saat ini, keberadaan fungsi langgar (mushalla) di Dusun Sekardangan masih terasa signifikan sebagaimana yang digambarkan Daulay di atas. Selain itu, keberadaan fungsi semua langgar (mushalla) di Dusun Sekardangan di antaranya adalah setiap satu bulan sekali digunakan oleh masyarakat sebagai tempat semaan Al-Qur'an secara bergilir, tempat mengajar pengetahuan agama Islam, diskusi ilmu-ilmu Islam oleh dan dari masyarakat sekitar. Adapun beberapa mushalla yang masih dipakai untuk kegiatan-kegiatan tersebut, di antaranya: Mushalla Al-Huda; Mushalla Baitut Tawwabin; Mushalla Al-Munawwir; dan lainnya. Usai semaan Al-Qur'an biasanya diisi pengajian agama Islam berupa masalah akidah, akhlak, ibadah dan semacamnya oleh kiai atau ulama setempat. Dengan demikian, fungsi langgar (mushalla) sebagai tempat pelembagaan nilainilai pendidikan Islam sejak dahulu hingga kini masih tetap berjalan semestinya.

Bermula dari institusi-institusi pendidikan Islam berupa rumah-rumah kiai, langgar (mushalla) tersebut, kemudian pada tahun 1900 muncul sebuah ide dari Kiai Imam Fakih, seorang ulama yang berasal dari Bagelenan, Jawa Tengah untuk menyatukan pengajaran pendidikan Islam ke dalam satu wadah berupa pesantren. Hasil wawancara dari Kiai Zainuddin (10/4/2020) dinyatakan bahwa ide dari Kiai Imam Fakih tersebut disambut dengan antusias oleh para kiai, tokoh masyarakat dan warga Dusun Sekardangan. Untuk mewujudkan ide tersebut, Kiai Imam Fakih dan para kiai lainnya beserta warga Dusun Sekardangan pada tahun 1900 kemudian berhasil mendirikan institusi pendidikan Islam berupa pesantren dan madrasah diniyah. Yakni, sebuah institusi pendidikan Islam yang lebih maju daripada institusi sebelumnya. Pesantren tersebut diberi nama "Pondok Pesantren Miftahul Huda" artinya tempat menimba ilmu para santri agar mendapatkan kunci petunjuk dari Allah SWT.

Adapun tenaga-tenaga pengajar di Pondok Pesantren Miftahul Huda dan madrasah diniyah pada masa Kiai Imam Fakih berasal dari beragam individu. Sebagian pengajar berasal dari anak-anak Kiai Imam Fakih sendiri, seperti: Kiai Imam Syadzali, Kiai Abbas Faqih, Kiai Mahfudz dan sebagian pengajar berasal dari anak-anak para keturunan pendiri langgar (mushalla) sebelumnya, seperti: Kiai Muhammad Irjaz, Kiai Hasyim, Kiai Ahmad Dasuqi, dan lain sebagainya. Sebagian pengajar ada yang berasal dari warga tetangga Dusun Sekardangan yang memang mempunyai kemampuan untuk mengajar keilmuan Islam. Menurut Kiai Zainuddin (12/4/2020) bisa digambarkan bahwa pada zaman itu banyak sekali pelajar-pelajar atau santri dari berbagai daerah luar Dusun Sekardangan (seperti dari Desa Tlogo, Kuningan, Banggle, dan lain sebagainya) yang menimba ilmu di lembaga pendidikan Islam berupa pesantren dan madrasah diniyah di dusun tersebut.

Dari berbagai pelajar atau santri di Pondok Pesantren Miftahul Huda Sekardangan masa itu dapat di kategorikan menjadi dua macam, yaitu: (1) Santri tetap, yakni pelajar atau santri yang berasal dari daerah lain dan bertempat tinggal menetap di pesantren. Pada masa Kiai Imam Fakih misalnya ada santri yang bernama Ahmad Shobiri berasal dari Pikatan, Wonodadi, Blitar yang menjadi santri tetap, hingga akhirnya diambil menantu oleh Kiai Imam Fakih; dan (2) Santri kalong, yakni pelajar/santri yang setiap sore hari datang ke pesantren lalu menginap sampai pagi, dan kemudian setelah itu ia pulang ke rumah masing-masing untuk membantu pekerjaan orang tua masing-masing. Dan esoknya dia juga melakukan 
hal yang sama. Biasanya, pelajar/santri yang demikian berasal dari dusun setempat atau rumah mereka berdekatan jaraknya dari pesantren.

Kembali ke pembahasan institusi pendidikan Islam di Dusun Sekardangan. Setelah Kiai Imam Fakih beserta warga Dusun Sekardangan berhasil mendirikan pesantren dan madrasah diniyah, kemudian muncul ide kreatif dari Kiai Imam Fakih untuk mendirikan sebuah masjid sebagai sarana beribadah dan institusi pendidikan Islam lainnya. Ide Kiai Imam Fakih tersebut juga disambut antusias oleh masyarakat Dusun Sekardangan. Untuk merealisasaikan ide tersebut, kemudian pada tahun 1990-an Kiai Imam Fakih menjual tanah miliknya kepada pihak Handels Vereniging Amsterdam (HVA) untuk dijadikan jalan kereta api pengangkut tebu milik Belanda, yang jaman itu tempat pengumpulan tebunya berada di Garum-Blitar. Dari hasil penjualan tanah tersebut dipakai bekal sebagai pendirian institusi pendidikan Islam berupa masjid. Dan masjid ini merupakan sebuah masjid pertama dalam sejarah Dusun Sekardangan. Pada mulanya, sejak tahun 1903 masjid tersebut dinamakan dengan "Masjid Miftahul Huda". Namun seiring berjalannya waktu, setelah masjid itu direhab pada tahun 1984, maka namanya diganti dengan sebutan "Masjid Baitul Makmur" (artinya tempat yang ramai untuk ibadah) yang tetap abadi hingga sekarang.

Tim Penyusun (1990: 14-15) dan Shofwan (2016: 25) menyatakan bahwa kepemimpinan institusi pendidikan Islam berupa Masjid Baitul Makmur di Dusun Sekardangan dari generasi ke generasi dapat dijelaskan sebagaimana berikut, yaitu: (1) Kiai Imam Fakih, tahun 1900-1923; (2) Kiai Imam Syadzali, tahun 1923-1925; (3) Kiai Ahmad Shobiri, tahun 1925-1951; (4) Kiai Abbas Fakih, tahun 1951-1960; (5) Kiai Imam Mahdi, tahun 1960-1997; (6) Kiai Muhammad Hamzah, tahun 19972002, dan pada masa kiai ini Pondok Pesantren Miftahul Huda berganti nama menjadi "Pesantren Ketrampilan Miftahul Huda" yang kurikulum pesantrennya memasukkan ketrampilan jahit-menjahit, pertukangan dan ketrampilanketrampilan lainnya; dan (7) Kiai Mashudi, tahun 2002 - sekarang, dibantu oleh Kiai Muhammad Munif dan Kiai Saiq Saiful Hadi yang diberi amanah untuk memegang masalah kemasjidan, sedangkan urusan kepesantrenan dipegang oleh Kiai Muhammad Tasrifin, yakni menantu dari Kiai Muhammad Hamzah.

Selain para kiai di atas, ada beberapa kiai mulai zaman kepemimpinan Kiai Imam Mahdi ke bawah (yakni seputar tahun 1960-2007) yang mempunyai kontribusi besar ikut serta dalam membangun peradaban pendidikan Islam dalam instritusi berupa masjid, pesantren, madrasah diniyah di lingkungan Dusun Sekardangan, antara lain: (1) Kiai Maulan, yakni seorang ulama yang masyhur mengajarkan ilmu hisab, ilmu fikih dan yang terkenal mempunyai suara yang sangat merdu dalam komunitas Ikatan Seni Hadrah Republik Indonesia (ISHARI); (2) Kiai Muhammad Machrus Yunus, yakni seorang ulama yang juga mengajarkan ilmu hisab, perintis Jamaah Shalawat Nariyah yang hingga kini masih berlangsung serta pendiri Sekolah Dasar Islam Plus Sunan Pandanaran yang berada di Dusun Sekardangan; (3) Kiai Nasruddin, yakni seorang ulama yang ahli dan mengajarkan ilmu tasawuf dan Tharikah Wahidiyah ajaran dari Syaikh Abdul Madjid Ma'roef (Kedunglo, Kediri); (4) Kiai Muhtar Fauzi, seorang ulama yang mengajarkan ilmu tauhid, amalan-amalan Hizib Auliya dan merupakan seorang yang menjadi cikal bakal berdirinya institusi pendidikan Islam formal pertama di Dusun Sekardangan; (5) Kiai Zainuddin, seorang ulama yang mengajarkan ilmu tasawuf Al-Ghazali dan

790 BRILIANT: Jurnal Riset dan Konseptual Volume 5 Nomor 4, November 2020 
menjadi cikal bakal berdirinya Jamaah Yasin, Tahlil dan Istigatsah di Dusun Sekardangan.

Selanjutnya, kurikulum pendidikan Islam yang diajarkan dalam institusi berupa Masjid Baitul Makmur dan Pondok Pesantren Ketrampilan Miftahul Huda dari sejak didirikan hingga sekarang dapat dijelaskan sebagai berikut, diantaranya: (1) Tafsir Al-Qur'an, meliputi: Tafsir al-Jalalain dan Tafsir al-Ibriz; (2) Ilmu Nahwu, meliputi: Kitab Al-Jurumiyah, Kitab Nadzam Al-Imrity dan semacamnya; (3) Ilmu Sharaf, meliputi: Kitab Al-Tasrif dan Qowa'idul I'rab; (4) Ilmu Fikih, meliputi: Kitab Al-Mabadi Al-Fiqhiyyah, Sullam Taufiq dan Fathul Qarib; (6) Ilmu Tajwid, meliputi: sorogan Al-Qur'an dan saat ini menggunakan Metode Ustmani. Selain itu, sejak masa Kiai Abbas Fakih dan Kiai Imam Mahdi, tampak institusi berupa masjid dan pesantren tersebut setiap dua tahun sekali telah mendatangkan ulama yang bisa mengajarkan dan mengijazahkan Shalawat Dalailul Khairat kepada masyarakat di dalam dan luar Dusun Sekardangan. Adapun beberapa kiai yang pernah tercatat pernah mengajarkan Shalawat Dalailul Khairat di masjid dan pesantren tersebut antara lain: (1) Kiai Dimyati, yakni seorang kiai yang terkenal sebagian dari wali Allah (min ba'dil Auliya) dari Baran, Selopuro, Blitar; (2) Kiai Machrus Ali, yakni seorang kiai Pengasuh Pondok Pesantren Lirboyo, Kediri; (3) Kiai Ali Shoddiq Umman; seorang kiai Pengasuh Pondok Hidayatul Mubtadi'in, Ngunut, Tulungagung.; (5) Kiai Harun Ismail dari Selopuro-Blitar; (6) Kiai Azizi Hasbulloh dari Selopuro-Blitar; (7) Kiai Abdul Aziz dari Paculgowang-Jombang; (8) Kiai Abdul Hannan Maksum dari Pare-Kediri; (8) Habib Abu Bakar dari Malang-Jatim; dan lain sebagainya.

2. Zaman Institusi Pendidikan Islam Formal (1966 - Sekarang)

Bermula dari berbagai institusi pendidikan Islam konvensional yang ada di Dusun Sekardangan seperti; rumah-rumah kiai, langgar (mushalla), masjid, pesantren hingga madrasah diniyah di atas, maka pada tahun 1966 masehi muncul sebuah ide kreatif dari Kiai Muhtar Fauzi (cucu dari Kiai Imam Fakih) bersama kawan-kawan perjuangannya (di antaranya: Kiai Muhammad Husnan, Kiai Muhammad Rubai, Kiai Maulan, Kiai Suroto, Kiai Masykur, dan lainnya) untuk melakukan pembaharuan dalam bidang pendidikan Islam. Ide kreatif dari Kiai Muhtar Fauzi dan kawan seperjuangannya tersebut mendapat sambutan yang hangat dari para tokoh agama Islam, dan masyarakat Dusun Sekardangan. Dari ide tersebut, maka tepat pada tanggal 05 Januari 1966 bersama segenap Ta'mir Masjid Baitul Makmur dan para tokoh masyarakat telah keluar izin dari dinas pemerintah terkait dan berhasil mendirikan institusi pendidikan Islam berupa madrasah formal pertama di Dusun Sekardangan yang diberi nama MI Miftahul Huda 01 dan TK AlHidayah 01 di dalam areal tanah wakaf dari Kiai Abbas Fakih (putra dari Kiai Imam Fakih).

Selanjutnya, berkaitan dengan hal ini, maka pencetus ide pertama dalam pendirian madrasah formal pertama di Dusun Sekardangan yakni Kiai Muhtar Fauzi kemudian ditunjuk oleh para tokoh dan alim ulama sedusun untuk menjadi kepala institusi berupa madrasah pertama di lembaga tersebut. Berikut merupakan data kepala MI Miftahul Huda 01 dari masa ke masa, antara lain: (1) Kiai Muhtar Fauzi, sejak 1966-1968; (2) Kiai Muhammad Hamzah, sejak 1968- 1975; (3) Kiai Masjhudi, BA., sejak 1975-1994; (4) Kiai Mustadji, A.Ma., sejak 1994-1997; (5) H. Marjani, A.Ma., sejak 1997-2007; (6) Lina Zunnuroiin, S.Pd.I., sejak 2007 sekarang. Adapun kepala TK Al- Hidayah dari masa ke masa dapat disebutkan 
sebagai berikut, antara lain: (1) Siti Djariah, 1966-1980, sebelum ini tersebut nama Siti Rubikah sebagai kepala TK, tetapi institusi TK saat itu masih berpindah-pindah dari rumah ke rumah; (2) $\mathrm{Hj}$. Mastiyah Machrus, A.Ma., yakni istri dari Kiai Muhammad Machrus Yunus sejak 1980-1986; (3) Siti Windarwati, S.Pd., sejak 1986-2012; (4) Solikah, A.Ma., sejak 2012-2016; dan (5) Baiti Sairurah, S.Pd.I., sejak 2016-sekarang.

\section{Karakteristik Pendidikan Islam Dari Masa ke Masa}

Pertama, tidak ada data yang menyebutkan tentang bagaimana sistem pengajaran institusi pendidikan Islam pada masa ketiga tokoh cikal-bakal ketika awal mendirikan atau bedol Dusun Sekardangan. Namun dalam sebuah wawancara dengan sesepuh bahwa petilasan ketiga tokoh yang berada di Dusun Sekardangan dan lazim disebut oleh warga sekitar sebagai "Petilasan Eyang Sekardangan" itu dahulu kala merupakan sebuah langgar (mushalla) kecil yang biasa dipakai untuk beribadah dan mengajarkan keagamaan Islam. Ada kemungkinan bahwa karakteristik pengajaran pendidikan Islam kala itu diajarkan secara sederhana, di antaranya melalui tembang-tembang macapat. Sebab pengajaran melalui tembangtembang macapat inilah yang biasa digunakan para tokoh Islam pada zaman Kerajaan Demak Bintara, Pajang, dan Mataram. Misalnya, pada masa-masa itu Sunan Kalijaga banyak mengajarkan nilai-nilai Islam melalui Kidung Rumeksa Ing Wengi dalam bentuk macapat. Begitu pula wali-wali pada masa Walisanga dan setelahnya (yakni; Masa Pajang dan Mataram), juga menggunakan media tembang macapat untuk mendidik masyarakat Jawa. Dengan demikian, ada banyak kemungkinan bahwa pengajaran pendidikan Islam di langgar (mushalla) yang didirikan ketiga tokoh cikal-bakal Dusun Sekardangan masa awal disampaikan melalui berbagai macam tembang macapat atau syair-syair lainnya.

Kedua, pada zaman institusi pendidikan Islam non-formal di Dusun Sekardangan, kurikulum yang digunakan masih sangat sederhana. Biasanya kitabkitab yang diajarkan adalah kitab-kitab klasik abad pertengahan yang berupa kitab komentar (syarah). Kurikulum yang digunakan masih berdasarkan tamat (khatam)nya berbagai kitab yang diajarkan. Bisa digambarkan pula bahwa sistem pengajaran yang digunakan pada zaman institusi pendidikan Islam non-formal di Dusun Sekardangan, di antaraanya: (1) Sorogan, yakni para pelajar tingkat dasar maju satu persatu kepada guru atau kiai yang bersangkutan untuk menguasai ilmu-ilmu dasar, seperti bacaan Al-Qur'an dan ilmu Nahwu-Sharaf. Sistem sorogan ini lazim digunakan di Dusun Sekardangan pada institusi pendidikan Islam berupa rumahrumah kiai, langgar (mushalla), masjid, pesantren, dan madrasah diniyah; (2) Bandongan, yakni sistem pengajaran yang digunakan bagi pelajar dewasa. Sistem ini digunakan di Dusun Sekardangan bagi pelajar dewasa yang mengkaji kitab-kitab tafsir Al-Qur'an di masjid, langgar dan pesantren. Biasanya para pelajar dewasa membentuk lingkaran (halaqah) di serambi Masjid Baitul Makmur Sekardangan dalam mengkaji kitab-kitab tafsir; (3) Musyawarah, yakni sistem pengajaran dengan cara melakukan diskusi sesama pelajar. Sistem ini biasa digunakan para pelajar di Dusun Sekardangan ketika mendiskusikan ilmu-ilmu tauhid di rumahrumah kiai, langgar, masjid, dan pesantren; (4) Ceramah/tabligh, yakni sistem pengajaran dengan mendatangkan pembicara/kiai dari luar maupun dalam Dusun Sekardangan. Biasanya, sistem ini digunakan di Dusun Sekardangan pada peringatan hari besar-besar Islam, khutbah Jumat, dan pengajaran Shalawat

792 BRILIANT: Jurnal Riset dan Konseptual Volume 5 Nomor 4, November 2020 
Dala'ilul Khairat kepada masyarakat sekitar (Bandingkan dengan Dhofier, 1994: 28-31).

Ketiga, sistem pengajaran pada zaman institusi pendidikan Islam formal (1966-sekarang) banyak menggunakan metode pengajaran modern. Walau tidak bisa dipungkiri pula bahwa sistem pengajaran lama atau tradisional (seperti; sorogan, bandongan, musyawarah, dan ceramah/tabligh) tetap digunakan. Hal tersebut menurut Kiai Muhammad Tasrifin (19/2/2020) didasarkan pada sebuah prinsip yang berbunyi "al-mukhafadhatu alal qadimish shalih wal akhdzu bil jadidil ashlah", artinya mempertahankan yang lama dan baik, serta mengambil yang baru yang lebih baik. Yakni, mempertahankan sistem pengajaran lama yang dianggap masih baik dan mengambil sistem pembelajaran baru/modern yang lebih baik. Dan hal itulah merupakan ciri khas yang digunakan para kiai di Dusun Sekardangan dalam melembagakan pendidikan Islam kepada masyarakat sekitarnya.

Adapun sistem pengajaran yang dipakai pada masa institusi pendidikan Islam formal berupa MI Miftahul Huda 01 dan TK Al-Hidayah 01 (1966-sekarang) biasanya menggunakan beberapa metode modern berikut, di antaranya: (1) metode ceramah, yakni memberikan pengertian dan uraian masalah; (2) metode diskusi, yakni memecahkan masalah dengan berbagai tanggapan; (3) metode eksperimen, yakni mencoba mengetahui proses terjadinya suatu masalah; (4) metode demonstrasi, yakni menggunakan alat peraga untuk memperjelas sebuah masalah; (5) metode pemberian tugas, yakni pemberian tugas kepada anak didiknya secara bebas dan tanggungjawab; (6) metode sosiodrama, yakni menunjukkan tingkah laku kehidupan; (7) metode drill, yakni melatih mengukur daya serap terhadap mata pelajaran; (8) metode kerja kelompok, yakni memecahkan masalah secara bersamasama dalam jumlah tertentu; (9) metode tanya jawab, yakni memecahkan masalah dengan cara umpan balik; (10) metode proyek, yakni memecahkan masalah dengan langkah-langkah secara ilmiah, logis, dan sitematis (Kamsinah, 2008: 106-107). Demikian inilah karakter dan metode pembelajaran yang digunakan pada institusi pendidikan formal pada umumnya. Metode-metode tersebut digunakan untuk menyesuaikan diri dengan perkembangan pendidikan yang ada saat ini agar tidak tergerus arus globalisasi.

\section{KESIMPULAN}

Berdasarkan pemaparan di atas dapat disimpulkan sebagai berikut, antara lain: Pertama, saat awal pendirian Dusun Sekardangan sekitar abad 15-16 M, ada banyak kemungkinan bahwa pengajaran pendidikan Islam dilakukan secara sederhana di langgar (mushalla) yang didirikan ketiga tokoh cikal-bakal Dusun Sekardangan masa awal dan disampaikan melalui berbagai macam tembang macapat atau syair-syair lainnya. Pengajaran melalui tembang-tembang macapat inilah yang biasa digunakan para tokoh Islam pada zaman Kerajaan Demak Bintara, Pajang, dan Mataram. Misalnya, pada masa-masa itu Sunan Kalijaga banyak mengajarkan nilai-nilai Islam melalui Kidung Rumeksa Ing Wengi dalam bentuk macapat. Begitu pula wali-wali pada masa Walisanga dan setelahnya.

Kedua, ketika masyarakat Dusun Sekardangan masih memiliki institusi pendidikan Islam non-formal (1700-1966), maka pengajaran ilmu-ilmu pengetahuan Islam seperti cara membaca Al-Qur'an, akidah, akhlak, dan ibadah banyak dilakukan di rumah-rumah kiai, langgar (mushalla), masjid, dan pesantren. Rumah-rumah kiai merupakan lembaga pendidikan Islam pertama di Dusun 
Sekardangan tampak signifikan dengan rumah sahabat Al-Arqam (Dar Al-Arqam) yang jaman Nabi Muhammad SAW dipakai mendidik para sahabat masa awal. Adapun karakteristik pengajaran pada masa ini masih banyak menggunakan sistem pengajaran tradisional berupa: sorogan, bandongan, musyawarah, dan ceramah/tablig kiai yang didatangkan dari luar Dusun Sekardangan.

Ketiga, setelah masyarakat Dusun Sekardangan telah memiliki institusi pendidikan Islam formal berupa MI Miftahul Huda 01 dan TK Al-Hidayah 01 (tahun 1966-sekarang), maka pengajaran ilmu-ilmu pengetahuan Islam dilakukan melalui metode pembelajaran yang lebih maju atau modern. Metode-metode pengajaran modern itu antara lain: metode ceramah; metode diskusi; metode eksperimen; metode demonstrasi; metode pemberian tugas; metode sosiodrama; metode sosiodrama; metode drill; metode kerja kelompok; metode tanya jawab; dan metode proyek.

Keempat, walaupun metode-metode modern yang lebih maju juga digunakan, namun dalam realitasnya pendidikan Islam di Dusun Sekardangan tidak serta merta meninggalkan sistem pengajaran tradisional sebelumnya yang dinilai masih baik. Penggunaan metode-metode baru yang lebih baik serta penjagaan metode-metode lama yang masih baik didasarkan pada idiom "al-muhafadhah alal qadimis shalih wal akhdu bil jadidil ashlah" (menjaga tradisi lama yang baik dan mengambil tradisi baru yang lebih baik) untuk menyesuaikan diri dengan perkembangan pendidikan yang ada saat ini agar tidak tergerus arus globalisasi.

\section{SARAN}

Tidak dipungkiri bahwa pendidikan tradisional berupa rumah-rumah kiai, langgar (mushalla), masjid, madrasah diniyah, dan semacamnya merupakan lembaga pendidikan Islam pertama/awal dalam berbagai studi kasus di Indonesia. Namun hal ini tampaknya belum banyak perhatian serius dari para peneliti yang fokus meneliti pada lembaga pendidikan Islam. Oleh karena itu, penelitian semacam ini sangat menarik apabila dilakukan diberbagai belahan daerah. Tidak menutup kemungkinan, ada banyak kesamaan apabila penelitian studi kasus semacam ini diperluas ke berbagai macam daerah di nusantara. Setidaknya, penelitian semacam ini akan memantik pada para praktisi pendidikan dan peneliti pendidikan Islam untuk mengadakan penelitian lanjutan.

\section{DAFTAR RUJUKAN}

Al-Abrashi, M. Athiyah (1969). Al-Tarbiyah Al-Islamiyah Wa Falasifatuha. Qahirah: Isa Al-Baby al-Halaby).

Arifin, M (2002). Perbandingan Pendidikan Islam. Jakarta: PT. Rineka Cipta.

Bilgrami, Hamid Hassan dan Syed Ali Ashraf (1985). The Concept of an Islamic University. Cambridge: The Islamic Academy.

Bogdan, Robert C. \& Sari Knopp Biklen (1998). Qualitative Research for Education: An Introduction to Theory and Methods. London: Allyn and Bacon.

Daulay, Haidar Putra (2009). Sejarah Pertumbuhan dan Pembaruan Pendidikan Islam di Indonesia. Jakarta: Kencana.

Dhofier, Zamakhsyari (1994). Tradisi Pesantren: Studi tentang Pandangan Hidup Kyai. Jakarta: Penerbit LP3ES.

794 BRILIANT: Jurnal Riset dan Konseptual

Volume 5 Nomor 4, November 2020 
Kamsinah (2008). Metode dalam Proses Pembelajaran Studi tentang Ragam dan Implementasinya. Lentera Pendidikan, Vol. 11, No. 1, Juni 2008: 101-114. Langgulung, Hasan (2003). Pendidikan Islam dalam Abad ke 21. Jakarta: Pustaka Al-Husna Baru).

Muhadjir, Noeng (1996). Metodologi Penelitian Kualitatif. Yogyakarta: Rake Sarasin.

Nazir, Moh (2011). Metode Penelitian. Jakarta: Penerbit PT. Ghalia Indonesia.

Nizar, Samsul (2005). Reformasi Pendidikan Islam Menghadapi Pasar Bebas. Jakarta: The Minagkabau Faoundation.

Partanto, Pius S., dan M. Dahlan Al-Barry (1994). Kamus Ilmiah Populer. Surabaya: Arkada.

Shofwan, Arif Muzayin (2016). Sekelumit Kisah Bumi Sekardangan dari Masa ke Masa. Blitar: The Post institute.

Soebahar, Abd. Halim (2002). Wawasan Baru Pendidikan Islam. Jakarta: Penerbit Kalam Mulia.

Spradley, J.P., (1997). Metode Etnografi, terj. Misbah Zulfa Elizabeth. Yogyakarta: Tiara Wacana.

----------, (1980). Participant Observation, Rinehart and Winston: Holt.

Stake, Robert E., "Case Studies", dalam Norman K. Denzin \& Yvonna S. Lincoln (ed.), 1994. Handbook of Qualitative Research. London: Sage Publications.

Sugiyono (2010). Memahami Penelitian Kualitatif: Disertai Contoh Proposal dan Laporan Penelitian. Bandung: CV. Alfabeta.

Tim Penyusun (1990). Sekilas tentang Masjid Baitul Makmur Sekardangan Kanigoro Kabupaten Blitar. Blitar: Ta'mir Masjid Baitul Makmur.

Ramayulis (2002). Ilmu Pendidikan Islam. Jakarta: Kalam Mulia.

Shalabi, Ahmad (1954). History of Muslim Education. Beirut: Dar Al-Kasyaf.

Qomar, Mujamil (2007). Pesantren Dari Transformasi Metodologi Menuju Demokratisasi Institusi. Jakarta: Erlangga.

Ziemek, Manfred (1986). Pesantren dalam Perubahan Sosial, terj. Butche B. Soendjojo. Jakarta: Perhimpunan Pengembangan Pesantren dan Masyarakat (P3M). 